Janusz Żołyński (i) https://orcid.org/0000-0001-7376-1693

Uczelnia Jana Wyżykowskiego w Polkowicach

\title{
RODO JAKO USTAWOWE ŹRÓDŁO PRAWA PRACY W ROZUMIENIU ART. 9 K.P.
}

\section{Abstract \\ GDPR as statutory source of labour law within the meaning of Art. 9 of the Labour Code}

This study shows that certain EU regulations, like GDPR which was directly implemented into the Polish legal system, are to be considered the source of labour law. Therefore, the collective agreements concluded on their basis must be considered the "peculiar" source of labour law. As a consequence, the collective agreements concluded on the basis of GDPR become the source of labour law in force in Poland, and thus are normative in nature.

Słowa kluczowe: ochrona danych osobowych, ochrona prywatności, ustawa, źródła prawa, prawo unijne Keywords: protection of personal data, privacy protection, act, source of law, EU law ASJC: 3308 , JEL: K31

\section{Wstęp}

Prawo pracy jest niewątpliwie prawem życia codziennego (Sanetra, Szurgacz 1975, s. 6), podobnie jak prawo cywilne, gdyż ludzie mają w zasadzie na co dzień z nim do czynienia. Z tego też względu uprawnione jest stawianie tezy, że szeroko rozumiane prawo pracy jest gałęzią prawa najbardziej związaną z przemianami społeczno-ekonomicznymi, jakie przeszła Polska od lat 1944/1945 do chwili obecnej.

Prawo to było także zawsze powiązane z uwarunkowaniami międzynarodowymi i relacjami w określonym kręgu geopolitycznym. Poprzednio Polska gospodarczo, co wpływało niewątpliwie na system pracy, związana była z tak zwanym blokiem RWPG ${ }^{1}$, który wymuszał społeczno-politycznie określone rozwiązania prawne.

${ }^{1}$ RWPG - Rada Wzajemnej Pomocy Gospodarczej. Powołana została w 1949 roku w Moskwie w celu koordynowania współpracy gospodarczej bloku państw podporządkowanych ZSRR, jako przeciwwaga dla tworzącego się na zachodzie Europy systemu gospodarczego, który doprowadził do powstania Europejskiej Wspólnoty Gospodarczej, a następnie Unii Europejskiej. Załamanie systemu 
Ze zbliżoną sytuacją, choć jednocześnie z uwagi na uwarunkowania polityczno-społeczno-gospodarcze diametralnie odmienną, mamy do czynienia przez ostatne kilkunaście lat. Otóż po zmianie ustrojowej w Polsce dokonanej po 1989 roku, a w szczególności po wejściu Polski do Unii Europejskiej w roku 2004, prawo krajowe niewątpliwie kształtowane jest niejednokrotnie przez regulacje prawnomiędzynarodowe. Są to nie tylko traktaty, konwencje międzynarodowe, lecz także - w głównej mierze - prawo przyjmowane na różnych szczeblach Unii. W szczególności odnosi się to do dyrektyw i rozporządzeń Parlamentu Europejskiego i Rady, które prowadzą do europeizacji polskiego prawa pracy i wprowadzają je w inny krąg kultury prawnej. Prawo Unii stało się mianowicie integralną częścią polskiego porządku prawnego, a zatem wpływa na prawo krajowe, gdyż dotyczy to instytucji i rozwiązań prawnych, które Unia reguluje swoimi aktami prawnymi. Cechą charakterystyczną prawa unijnego, w tym prawa pracy, jest zatem jego wertykalny charakter obowiązywania. Otóż obowiązki ustanowione w normach prawa Unii na poziomie ponadnarodowym adresowane są do państw członkowskich, zobowiązując je z kolei do wdrożenia standardów tego prawa do krajowego porządku prawnego.

$Z$ powyższego wynika nadrzędna pozycja instytucji unijnego prawa w stosunku do odpowiednich instytucji prawa pracy poszczególnych państw członkowskich Unii Europejskiej. Mimo że regulacje unijne rozmaicie oddziałują na polskie prawo pracy, niewątpliwie wpływają jednak znacząco na podniesienie poziomu ochrony pracowników, gdyż regulacje te mają charakter normatywny, a więc stanowiący podstawę do dochodzenia praw (roszczeń).

W chwili obecnej takim szczególnym przykładem jest rozporządzenie unijne dotyczące ochrony danych osobowych. W tym też względzie na gruncie prawa pracy rodzi się pytanie, czy akt ten może być uznany za źródło prawa pracy w rozumieniu art. 9 ustawy z dnia 26 czerwca 1974 roku - Kodeks pracy (Dz.U. 2019, poz. 1040 tekst jedn. ze zm., dalej: Kodeks pracy, k.p.).

\section{2. Źródła prawa pracy}

Przed dokonaniem analizy podstaw prawnych w zakresie oceny możliwości uznania tak zwanego rozporządzenia RODO (Rozporządzenie Parlamentu Europejskiego i Rady (UE) nr 2016/679, Dz.Urz. UE L 2016, nr 119/1) za źródło prawa pracy należy niewątpliwie, co najmniej syntetycznie, odwołać się do samego pojęcia „źródło prawa”. Otóż problem źródeł prawa to przede wszystkim zagadnienie hierarchii mocy obowiązującej aktów normatywnych kreujących określone stosunki prawne, a w naszym przypadku stosunki pracy. Niemniej zagadnienie źródeł prawa należy do domeny teorii prawa i wypracowane tam zasady są wiążące także dla prawa pracy. Nie wchodząc w szczegółowe

komunistycznego w europejskich krajach satelickich ZSRR po 1989 roku oraz zmiany w ZSRR doprowadziły w roku 1991 w Budapeszcie do rozwiązania Rady. 
rozważania prawne, przez źródło prawa możemy rozumieć akty normatywne i inne reguły postępowania uznane (sankcjonowane) przez państwo (Rot 1992, s. 47), a zatem akty ustanawiające normy prawa obowiązującego. W konsekwencji są to zatem takie akty prawa, które zawierają co najmniej jedną normę generalną lub abstrakcyjną, mogącą być podstawą do indywidualnych rozstrzygnięć (Banaszak 2012, s. 38). Na podstawie art. 87 Konstytucji Rzeczypospolitej Polskiej z dnia 2 kwietnia 1997 roku (Dz.U. 1997, nr 78, poz. 483 ze zm., dalej: Konstytucja RP, Konstytucja) źródłami powszechnie obowiązującego prawa Rzeczypospolitej Polskiej są: Konstytucja, inne ustawy, ratyfikowane umowy międzynarodowe oraz rozporządzenia, a także akty prawa miejscowego. W zakresie źródeł obowiązuje zasada prymatu Konstytucji. Nadrzędność jej mocy w systemie źródeł prawa powoduje, iż wszelkie akty prawne niższego rzędu muszą być z nią zgodne. Stąd bierze się waga poszczególnych przepisów konstytucyjnych. Określenie poszczególnych zagadnień materialnych, ustrojowych czy proceduralnych oddziałuje na cały porządek prawny.

W sferze prawa pracy sytuacja wygląda nieco odmiennie, gdyż zgodnie z art. 9 k.p. źródłem prawa pracy są Kodeks pracy oraz inne ustawy i akty wykonawcze określające prawa oraz obowiązki pracowników i pracodawców. Źródłem prawa mogą być także układy zbiorowe pracy i oparte na ustawie porozumienia zbiorowe, regulaminy oraz statuty określające prawa i obowiązki stron stosunku pracy. Kodeks pracy, mimo wielu nowelizacji², nie odwołuje się „,wzorem” Konstytucji RP do uznania, że źródłem prawa pracy są ratyfikowane umowy międzynarodowe lub - z uwagi na wejście Polski do Unii Europejskiej - akty prawne stosownych organów unijnych. Stąd powstaje istotne zagadnienie odnośnie do charakteru prawnego, na przykład w zakresie tak zwanych rozporządzeń unijnych (na uboczu pozostawiam dyrektywy, które wymagają implementacji do polskiego systemu prawnego), jako podstawy zawierania porozumień zbiorowych.

\section{Charakter prawny RODO - prawo prywatne czy prawo publiczne}

Analiza przedstawionego tematu byłaby niekompletna bez rozważań dotyczących charakteru prawa. Otóż w prowadzonym dyskursie doktrynalnym powstaje pytanie o charakter regulacji prawnych: czy są to regulacje z zakresu prawa prywatnego, czy też publicznego. Chodzi mianowicie o zakres uprawnień adresatów norm prawnych i możliwość władczej ingerencji przez podmioty trzecie (problematyka relacji: prawo prywatne a prawo publiczne w odniesieniu do prawa pracy została omówiona przez: Żołyński 2016b). Rozstrzygnięcie tego zagadnienia ma istotne znaczenie, gdyż prawo pracy ma charakter publicznoprawny, a więc do uznania, że RODO może być źródłem prawa pracy, należy określenie charakteru prawnego tego aktu. W tym też względzie należy

2 Tylko do 2014 roku Kodeks pracy miał aż sto jeden nowelizacji, co skutkowało zmianą dwustu dziewięćdziesięciu czterech przepisów. Ponadto dodano dwieście cztery przepisy, uchylono trzydzieści jeden przepisów, a nie zmieniono jedynie dwudziestu pięciu (Florczak, Muszyńska 2014). 
zwrócić uwagę, że w doktrynie polskiego prawa pracy powszechny i dominujący jest pogląd, że w indywidualnym prawie pracy mamy do czynienia z dwoma kontrahentami, z których jeden - pracodawca - jest podmiotem dominującym, a pracownik jest słabszą stroną stosunku pracy, na której ochronę zorientowane są przepisy Kodeksu pracy (doktryna funkcji ochronnej prawa pracy). W myśl tej koncepcji (monistycznej) prawo pracy jest reakcją na dominację pracodawcy nad pracownikiem. Taki pogląd przyjmuje także Trybunał Konstytucyjny wskazując, że z art. 24 Konstytucji (w związku z jej art. 65) wynika obciążenie państwa obowiązkiem „ochrony pracowników jako słabszej strony stosunku pracy, a w konsekwencji obowiązek stworzenia określonych gwarancji prawnych dotyczących zarówno ochrony osoby pracownika, jak i jego interesów, w tym ochrony przed niezgodnymi z prawem bądź nieuzasadnionymi działaniami pracodawców" (wyrok Trybunału Konstytucyjnego z dnia 22 maja 2013 roku, P 46/11, Dz.U. 2013, poz. 653; Florek 1997, s. 197; wyroki Trybunału Konstytucyjnego: z dnia 18 października 2005 roku, SK 48/03, OTK-A 2005, nr 9, poz. 101; z dnia 24 października 2006 roku, SK 41/05, Dz.U. 2006, nr 198, poz. 1464; z dnia 12 lipca 2010 roku, P 4/10, Dz.U. 2010, $\mathrm{nr}$ 135, poz. 912). Z uwagi na zachodzącą nierównorzędność w relacjach pracownikpracodawca występuje zatem konieczność władczego wkroczenia państwa. Dotyczy to między innymi sfery ochrony danych osobowych. Stąd rodzi się pytanie: czy materia regulowana przez RODO ma wymiar prywatny, czy publiczny?

Niewątpliwie celem regulacji RODO jest ochrona prywatności człowieka, w tym także pracownika. Otóż prawo musi chronić prywatność każdego człowieka, gdyż w przeciwnym razie nastąpiłoby zatarcie granic między państwem a społeczeństwem. Prywatność jest bowiem podzbiorem godności, wyrazem człowieczeństwa, autonomii człowieka, jego własnej woli oraz indywidualnego sumienia każdej osoby, w tym także szacunku do dokonanego wyboru. Stąd z istoty swojej prywatność przynależy do prawa prywatnego, gdyż ta sfera życia człowieka podlega ochronie wyłącznie z uwagi na interes zainteresowanego podmiotu, którego prywatność została naruszona lub zagrożona. Jest zatem wyrazem wolności. Państwo nie może wkraczać w tę sferę życia w tym znaczeniu, że nakazuje bezwzględną ochronę prywatności, nawet wbrew woli zainteresowanej osoby. Państwo może wyznaczać jedynie granice ochrony prywatności, określając aksjomaty tej ochrony, pozostawia jednak każdemu podmiotowi autonomię w dochodzeniu swoich praw ${ }^{3}$. Wolne społeczeństwo, a więc demokratyczne państwo prawa, realizuje bowiem funkcję wolności, którą jest pozostawienie jednostce prawa wyboru w sferze prywatnej. Przeciwstawia się jednej i słusznej wizji, a zatem uznaje szacunek dla innych wyborów. Sprzeciwia się totalizacji prawa. Szacunek dla prywatności jest szacunkiem dla godności innych, a zatem jest szacunkiem dla uniwersalnego prawa moralnego. Niemniej, jak wspomniano wyżej, obowiązkiem państwa, a więc podmiotów publicznych (przez które rozumieć należy także organy podmiotów o charakterze

${ }^{3}$ Notabene wymiar prywatny przejawia się także w tym, że nie można wyznaczyć granic prywatności, to jest określić wszystkich kategorii tego pojęcia. Z tego też względu ani na gruncie polskim, ani zagranicznym prywatność nie jest definiowana. 
ponadnarodowym), jest zapewnienie również ochrony prywatności, gdyż w stanowieniu prawa i następnie jego bezpośrednim stosowaniu należy uwzględnić również kwestie oraz sprawy społeczne, dla których używam zbiorczego określenia „socjalizacja prawa” (Żołyński 2016a, s. 54-56), mające ze swojej istoty charakter złożony. Stąd niewątpliwie RODO ma do zrealizowania coś więcej niż cele prywatne jego adresatów. Chronić ma także dobra należące do kategorii praw człowieka, a więc nie tylko chronione przez prawo prywatne. W przeciwnym razie, gdyby były to jedynie cele prywatne, nie byłyby chronione przez najwyższy akt prawny w państwie (Konstytucję RP) czy akty niższego rzędu, jak na przykład ustawa o ochronie danych osobowych (Dz.U. 2019 poz. 1781 tekst jedn.) czy Kodeks pracy. Zatem RODO ma wyraźnie także aspekt publiczny, ponieważ w materię ochrony wkraczają regulacje określające sposób postępowania; bo jedną z funkcji powyższej regulacji jest zapewnienie ochrony prywatności pracownika; gdyż - jak wspomniano - pracownik pozostaje na słabszej pozycji wobec pracodawcy. Okoliczność ta powoduje, że zachodzi związek zawierania między pracą a prywatnością pracownika w różnej postaci. Występuje zatem związek funkcjonalny. Chodzi o to, by pracownik nie odczuwał negatywnych skutków związanych z pracą, gdyż te negatywne oddziaływania mogą mieć wpływ na jego życie osobiste oraz na przebieg pracy obecnie oraz w przyszłości. Prywatność winna być zatem rozpatrywana nie tylko w wymiarze podmiotowym, to znaczy pod względem ochrony adresatów tego prawa, lecz także pod względem przedmiotowym. Przez pojęcie to rozumiem to, że prywatność nie ma charakteru erga omnes, prawa bezwzględnego (co wynika także z regulacji prawa międzynarodowego). Od strony aksjologicznej prawo pozytywne winno zakreślać granicę, za którą prywatność w sferze normatywnej z wymiaru prywatnoprawnego przeistacza się w prywatność $\mathrm{w}$ wymiarze publicznoprawnym, a więc wyznaczać granice upublicznienia tego prawa. Można powiedzieć, że prywatność kończy się wtedy, gdy zachodzi konieczność ochrony szeroko rozumianego dobra powszechnego.

Reasumując niniejszą sekwencję, genetycznie prywatność należy zaliczyć do kategorii prawa cywilnego. Jednakże samo RODO, normujące pewien fragment prywatności, jaką jest wyłącznie przedmiot ochrony danych osobowych, należy zaliczyć do sfery publicznej. Realizuje mianowicie prawa człowieka w postaci ochrony prywatności (którą to prywatność należy zaliczyć do praw człowieka pierwszej generacji), a w ogólności prawa człowieka są to publiczne prawa podmiotowe, które nie są prawami wzajemnymi. Rozporządzenie RODO przynależy w ramach prawa publicznego do szeroko rozumianego prawa nie tyle sensu stricto administracyjnego, ile prawa o cechach prawa administracyjnego. Prawo administracyjne jest to bowiem dział zaliczany do prawa publicznego obejmujący ogół norm regulujących między innymi zachowanie się osób fizycznych i innych podmiotów w zakresie nieunormowanym przez przepisy należące do innych działów prawa. Ponadto stanowisko to wynika $\mathrm{z}$ tego, że prawo administracyjne zawiera takie cechy, które posiada również RODO. Otóż z RODO wynika, że:

1. „Decyzja” co do zastosowania jego postanowień jest wynikiem w dużej mierze działań specjalnych podmiotów publicznych (na przykład co do zakresu możliwości i wysokości nakładania kar finansowych za nieprzestrzeganie RODO); 
2. Adresat postanowień RODO nie może uchylić się od skutków decyzji podmiotu publicznego;

3. Relacje między podmiotem publicznym a adresatem jednostronnie ustala podmiot publiczny;

4. Adresat regulacji RODO nie może uchylić się od stosowania tego prawa, a więc winien „dążyć do realizacji zawartego w nim celu (funkcji prawa);

5. RODO reguluje prawa i obowiązki ogółu jednostek zobowiązanych do jego przestrzegania;

6. RODO realizuje stoi na straży interesu publicznego;

7. I na koniec: według RODO odpowiedzialność za realizację prawa ponosi adresat.

RODO jest ze sfery prawa administracyjnego (lecz - jak wspomniałem - nie jest prawem administracyjnym sensu stricto), gdyż w wielu regulacjach posługuje się tak zwanym władztwem ${ }^{4}$, na przykład w zakresie przywołanych już możliwości nakładania kar finansowych, zakazu gromadzenia określonych danych osobowych, nakazu ich usunięcia ze zbioru danych czy zasad ich przetwarzania, co jest istotną cechą prawa administracyjnego. Ponadto jeżeli uznamy, że dla realizacji norm prawa administracyjnego niezbędne jest:

1) istnienie podstawy prawnej działania,

2) istnienie właściwego organu, który może działać,

3) organ zadziała, jeżeli ziszczą się określone w prawie przesłanki; z własnej inicjatywy lub z inicjatywy zainteresowanego podmiotu, - to RODO de facto i de iure spełnia wszystkie powyższe przesłanki ${ }^{5}$.

\section{Rozporządzenie RODO jako źródło prawa pracy}

Jak już wspomniano, od momentu wejścia Polski do Unii Europejskiej wiele regulacji prawa europejskiego weszło wprost do polskiego porządku prawnego. Dotyczy to także regulacji prawa pracy, gdyż prawo pracy Unii ma taki sam charakter jak całe prawo unijne, ponieważ w szczególności cechą prawa unijnego jest jego pierwszeństwo nad

${ }^{4}$ W znacznym uproszczeniu: cechą władztwa jest jego natura prawna oraz nierównoprawna pozycja stron. Znamię władztwa jest wtedy, gdy w granicach określonych prawem przedmiotowym (tj. podstawą stosunku) oświadczenie organu państwa ustala dla uczestnika stosunku powinność, możność, obowiązek, uprawnienie itp. (między innymi: Longchamps 1964, s. 45 i n.).

${ }^{5}$ Osobno w literaturze w ogóle prawo ochrony danych osobowych zalicza się do prawa publicznego, a w polskich realiach traktowane jest tradycyjnie jako element systemu prawa administracyjnego. Podstawowym bowiem celem publicznoprawnej ochrony danych osobowych jest wzmocnienie autonomii jednostki w szczególności w sferze prywatności. Dokonywane jest to za pomocą procedur o charakterze administracyjnym i związanych z nim środków technicznych, które są typowymi instrumentami prawa publicznego. Prywatność w zakresie ochrony danych osobowych chroniona jest zatem za pomocą instrumentów prawa publicznego. W konsekwencji powoduje to powstanie tak zwanej prywatności informacyjnej, na którą składają się uprawnienia jednostki do kontroli dotyczących jej treści i obiegu informacji na jej temat (Lityński 2017). 
prawem krajowym państw członkowskich (supremacy of Community law), zwane również niekiedy nadrzędnością prawa.

Drugą cechą prawa unijnego jest jego bezpośrednie obowiązywanie (direct applicability; Florek 1998, s. 5) co oznacza, że norma prawna ustanowiona przez organa unijne jest automatycznie wprowadzana do wewnętrznego porządku prawnego państw członkowskich i nie wymaga żadnego dodatkowego działania ze strony tych państw6 ${ }^{6}$. Następuje zatem faktyczna inkorporacja unijnych przepisów prawa pracy do wewnętrznego systemu prawnego Polski, bez potrzeby ich implementacji . Niemniej należy wyraźnie zwrócić uwagę, że stosowanie unijnego prawa nie oznacza tylko bezpośredniego odwołania się do stosownych regulacji wspólnotowych ${ }^{8}$. Przez stosowanie unijnego prawa należy mieć także na uwadze uwzględnianie bogatej wykładni dokonywanej przez orzecznictwo Trybunału Sprawiedliwości Unii Europejskiej. Wszystko to bowiem razem stanowi acquis communautaire (dorobek wspólnotowy), który musi być przestrzegany przez państwa członkowskie (Florek 2004, s. 2-8). Z tego też względu uprawnione jest uznanie, że wymiar sprawiedliwości Unii Europejskiej jest polskim wymiarem sprawiedliwości i na odwrót: polski wymiar sprawiedliwości jest systemem globalnego wymiaru sprawiedliwości Unii.

Jedną z regulacji unijnych wchodzących bezpośrednio do polskiego porządku prawnego jest przywołane rozporządzenie RODO. Jednakże przed rozważeniem istoty problemu należy zauważyć, że rozporządzenie RODO jest tak zwanym wtórnym prawem unijnym, gdyż za "pierwsze” należy uznać traktaty tworzące Wspólnotę Europejską, a obecnie Unię Europejską (traktaty rzymskie z dnia 25 marca 1957 roku; Jednolity Akt Europejski z dnia 17 lutego 1986 roku; Traktat o Unii Europejskiej, zwany też traktatem z Maastricht, z dnia 7 lutego 1992 roku; traktat amsterdamski z dnia 2 października 1997 roku; traktat nicejski z dnia 26 lutego 2001 roku oraz traktat lizboński z dnia 17 grudnia 2007 roku; za: Walczak 2017, s. 161). Jest wtórnym prawem, a więc przynależy

${ }^{6} \mathrm{Na}$ marginesie rozważań należy zauważyć, że na podstawie stosownych regulacji konstytucyjnych lub stanowiska judykatury konwencje MOP oraz traktaty międzynarodowe Rady Europy obowiązują ex lege lub inkorporowane ad hoc zajmują w hierarchii krajowego prawa pracy w większości krajów europejskich wyższą pozycję od ustaw. W innych krajach mają zagwarantowaną co najmniej równą pozycję z aktami stanowionymi przez organa ustawodawcze (Świątkowski 2008, s. 292).

${ }^{7} \mathrm{~W}$ piśmiennictwie polskim wskazuje się, że w doktrynie międzynarodowego prawa pracy rozróżnia się dwie postacie umów międzynarodowych:

A. Umowy tak zwane self-executory (samowykonalne, bezpośrednio skuteczne), określane także jako directly applicable (bezpośrednio stosowane) lub directly effective (bezpośrednio skuteczne). Umowy te działają bezpośrednio $\mathrm{w}$ wewnętrznym porządku prawnym, bez potrzeby ich powtarzania czy uszczegóławiania w ustawie. Za takie umowy uznaje się akty, które są dostatecznie jasne, bezwarunkowe, a ich wykonanie nie jest uzależnione od dalszych działań państwa poza ratyfikacją. Mogą one zatem stanowić podstawę bezpośrednich podmiotowych praw indywidualnych.

B. Umowy tak zwane executory, które wymagają wykonania (przyjęcia stosownego aktu prawnego na gruncie polskim). Zob. Florek 2000, s. 94 i n.; Świątkowski 2008.

${ }_{8}^{8}$ W wyroku z dnia 19 lutego 2014 roku (II PK 131/13, MPP 2014, nr 7, s. 372-375) Sąd Najwyższy sformułował następującą tezę: „Sąd Najwyższy nie jest uprawniony do dokonywania wykładni prawa Unii Europejskiej”. 
do regulacji unijnych, które oddziałują na sytuację prawną w poszczególnych krajach. Celem prawa wtórnego jest doprowadzenie do wyrównania poziomu społecznego i gospodarczego w całej Unii. Z tego też względu, mając na uwadze między innymi zapewnienie jednolitego stosowania, przedmiotowe rozporządzenie (jak zresztą każde inne) jest publikowane tylko i wyłącznie w Dzienniku Urzędowym Unii Europejskiej. Konsekwencją tego jest również to, że państwa członkowskie nie mają prawa do jego ogłoszenia w swoich wewnętrznych promulgatorach (Florek 1998, s. 161-162).

Powracając do podstawowego nurtu rozważań, należy wskazać, że niezbędne dla polskiego porządku konstytucyjnego oraz hierarchii źródeł prawa jest odwołanie się do art. 91 ust. 3 Konstytucji (Nowak 2018). Otóż zgodnie z nim prawo stanowione przez organizację międzynarodową, do której należy Polska, jest stosowane bezpośrednio i ma pierwszeństwo przed ustawami, jeżeli wynika to z umowy konstytuującej tę organizację; w tym względzie przez umowę konstytuującą należy rozumieć Traktat o funkcjonowaniu Unii Europejskiej (Dz.Urz. UE C 2016, nr 202, s. 1, dalej: Traktat o funkcjonowaniu Unii Europejskiej, TFUE), o czym dalej. Niewątpliwie zakresem art. 91 ust. 3 Konstytucji objęte są przepisy prawa wtórnego Unii, a zatem rozporządzenia (Banaszak 2012, s. 536-537), które na mocy art. 87 ust. 1 w zw. z art. 91 ust. 1 Konstytucji stanowią część polskiego porządku prawnego. Rozporządzenia unijne nie mają jednak pierwszeństwa przed Konstytucją, niemniej w razie kolizji normy prawnej wynikającej z tak zwanego rozporządzenia unijnego $\mathrm{z}$ normą rangi ustawowej lub normą zawartą $\mathrm{w}$ akcie prawnym niższego rzędu należy stosować rozporządzenie (Haczkowska 2014, art. 91 Konstytucji). $\mathrm{Z}$ tego też względu na gruncie prawa pracy w razie kolizji z Kodeksem pracy lub innym aktem ustawowym (lub niższego rzędu) regulującym szeroko rozumianą sferę prawa pracy, RODO korzysta z pierwszeństwa.

W celu rozstrzygnięcia problemu, czy RODO może być uznane za źródło prawa pracy, niezbędne jest także odwołanie się do stosownych regulacji prawa unijnego, które określają źródła prawa unijnego' a mianowicie do Traktatu o funkcjonowaniu Unii Europejskiej. Otóż zgodnie z art. 288 TFUE $^{10}$ (były art. 249 Traktatu ustanawiającego Wspólnotę Europejską, Dz.Urz. UE C 2012, nr 326/47) instytucje Unii przyjmują rozporządzenia, dyrektywy, decyzje, zalecenia i opinie. Rozporządzenie jako akt prawny ma zasięg ogólny, jest wiążące w całości oraz bezpośrednio stosowane we wszystkich państwach członkowskich. Ponadto rozporządzenia mogą być skierowane do nieograniczonej liczby podmiotów, zarówno do rządów, jak i do osób fizycznych. Stąd ich transformacja przez państwa członkowskie jest nie tylko zbędna, lecz i niedopuszczalna (Emmert,

9 W przeciwieństwie do katalogu źródeł prawa polskiego katalog europejski pozostaje otwarty (Wróbel 2012, s. 621).

${ }^{10}$ Artykuł 288 wyraźnie postanawia, że „W celu wykonania kompetencji Unii instytucje przyjmują rozporządzenia, dyrektywy, decyzje, zalecenia i opinie. Rozporządzenie ma zasięg ogólny. Wiąże w całości i jest bezpośrednio stosowane we wszystkich Państwach Członkowskich. Dyrektywa wiąże każde Państwo Członkowskie, do którego jest kierowana, w odniesieniu do rezultatu, który ma być osiągnięty, pozostawia jednak organom krajowym swobodę wyboru formy i środków. Decyzja wiąże w całości. Decyzja, która wskazuje adresatów, wiąże tylko tych adresatów. Zalecenia i opinie nie mają mocy wiążącej”. 
Morawiecki 2002, s. 110). Z kolei decyzje, zalecenia i opinie nie mają charakteru prawa powszechnie obowiązującego. Decyzje są wiążące jedynie wobec ich adresatów (oznaczonych indywidualnie), a zalecenia i opinie w ogóle nie mają charakteru wiążącego.

Odwołanie się do regulacji unijnych ma to znaczenie, że art. 9 k.p., wskazując, które akty prawa krajowego uznawane są za źródła prawa pracy, używa terminu „ustawowe źródło prawa". Należy zatem dokonać co najmniej syntetycznego zbadania, czy akt prawny w postaci „rozporządzenia” $\mathrm{w}$ rozumieniu prawa unijnego jest równoznaczny z pojęciem „ustawa” w rozumieniu prawa polskiego. Otóż trzeba zauważyć, że ustawa jako akt prawny w rozumieniu prawa polskiego:

1) jest najwyższym aktem prawnym przyjmowanym w Polsce (oczywiście pomijam tutaj materię będącą przedmiotem Konstytucji),

2) jest uchwalana wyłącznie przez parlament,

3) jest przyjmowana w specjalnej procedurze,

4) ma przedmiotowo nieograniczony charakter, a jej tak zwaną materią ustawową jest zakres spraw, które mogą być regulowane jedynie tym aktem prawnym, na przykład wyłącznie sprawy dotyczące praw i wolności oraz obowiązków obywateli (Wronkowska 2005, s. 41).

Powyższe kryteria niewątpliwie spełnia rozporządzenie Parlamentu Europejskiego i Rady. Mianowicie:

- jest ono wymieniane przez przywołany art. 288 TFUE na pierwszym miejscu jako „najwyższy” akt prawny,

- uchwalane jest przez Parlament Europejski,

- przyjmowane jest w specjalnej procedurze, która jest określona przez art. 294 TFUE,

- jest aktem o najszerszym zasięgu,

- może być skierowane do nieograniczonej liczby podmiotów, zarówno do rządów, jak i do osób fizycznych.

Przedstawiona powyżej argumentacja upoważnia do uznania, że rozporządzenia unijne są zrównane nie tylko terminologicznie, lecz także normatywnie z ustawą w rozumieniu prawa polskiego ${ }^{11}$, a nawet więcej - są nad ustawą. Niemniej ze względu na swój specyficzny charakter rozporządzenia Unii Europejskiej powinny być traktowane nie jako ustawa, lecz jak ustawa. Skoro rozporządzenia winny być traktowane jak ustawa, to mogą być w świetle art. 9 k.p. źródłem prawa pracy. Za powyższym rozumowaniem przemawiają:

1) Bezpośrednia, co wskazałem wcześniej, inkorporacja unijnych przepisów prawa pracy do wewnętrznego systemu prawnego Polski, bez potrzeby ich implementacji, a tym samym uznanie obu systemów prawnych (unijnego i krajowego) za

${ }^{11}$ Na marginesie - uważam, że ratyfikowane umowy międzynarodowe czy ratyfikowane konwencje MOP, jeżeli regulują prawa i obowiązki między pracodawcą a pracownikami, są źródłem prawa pracy, a zatem mogą stanowić podstawę do zawierania porozumień zbiorowych pracy. Stanowisko to posiada uzasadnienie prawne w tym, że generalnie ratyfikacja umowy międzynarodowej wymaga uprzedniej zgody wyrażonej w formie ustawy, gdy dotyczy wolności, praw lub obowiązków obywatelskich określonych w art. 89 Konstytucji. Zatem generalnie podstawą ich obowiązywania jest ustawa sejmu RP. 
dorobek wspólnotowy. Konsekwencją tego jest to, że normatywnie regulacje prawa krajowego mają faktycznie i w przestrzeni prawnej charakter, wymiar dualny (podwójną naturę) - są to zarówno bezpośrednie regulacje stanowione przez organy krajowe oraz regulacje wchodzące do krajowego porządku prawnego w wyniku przyjęcia unormowań przez stosowne instytucje unijne.

2) Zastosowanie wykładni celowościowej. Otóż, przepisy prawa unijnego na gruncie krajowym winny być interpretowane zgodnie z wykładnią celowościową ${ }^{12}$, a nie $\mathrm{z}$ dominującą $\mathrm{w}$ Polsce wykładnią językową ${ }^{13}$.

Konsekwencją powyższego jest to, że normatywnie rozporządzenie RODO może być bezpośrednim źródłem roszczeń indywidualnych dochodzonych przez pracowników przed sądami pracy (na przykład w zakresie dochodzenia zadośćuczynienia z powodu naruszenia dóbr osobistych będącego konsekwencją ujawnienia danych osobowych).

\section{RODO jako podstawa prawna zawierania porozumień zbiorowych pracy}

Logiczną konsekwencją poczynionych dotychczas wywodów jest to, że skoro rozporządzenie Parlamentu Europejskiego może być źródłem prawa pracy, to może być tym samym podstawą do zawierania porozumień zbiorowych w świetle art. 9 k.p. Powyższą argumentację umacnia także to, że:

1. W Unii Europejskiej obowiązuje zasada pierwszeństwa prawa unijnego przed prawem krajowym. Skoro RODO używa w swojej treści sformułowań „porozumienia

${ }_{12}$ Za zastosowaniem pierwszeństwa tej wykładni na gruncie prawa polskiego opowiada się Cieśliński (2003, s. 24). Zwolennikiem stosowania przez sądy wykładni funkcjonalno-celowościowej i uznania jej pierwszeństwa przed wykładnią gramatyczną jest Jaśkowski (2007, s. 77-78), co jego zdaniem daje prymat paremii lex est ars boni et aequi nad dura lex, sed lex. Za kierunkiem tym opowiada się także Walerian Sanetra, stwierdzając, że z uwagi na niski poziom stanowionego prawa Sąd Najwyższy nie zawsze powinien dawać prymat dyrektywom językowym, lecz niekiedy - systemowym i funkcjonalnym. Jego orzeczenia zasadniczo powinny mieć charakter precedensowy i powinien być w nich zawarty element prawotwórstwa (Sanetra 2006, s. 21-23). Pogląd ten w całości akceptuje i konsekwentnie prezentuje również Żołyński, na przykład w glosie do wyroku Sądu Najwyższego z dnia 4 września 2013 roku w sprawie dopuszczalności zawierania więcej niż jednej umowy o pracę na okres próbny z tym samym pracodawcą (II PK 358/12, LEX nr 1460947) czy w książce Aksjologiczne, normatywne i społeczne podstawy prawa rozwiązywania sporów zbiorowych pracy (2014; 2016a, s. 302 i n.). Ponadto należy zwrócić uwagę, że pierwszeństwo w stosowaniu wykładni celowościowej wobec wykładni językowej wynika wprost z niektórych postanowień Kodeksu cywilnego (Dz.U. 2019, poz. 1145 tekst jedn. ze zm.), na przykład w art. $65 \$ 2$ wyraźnie wskazano formułę interpretacyjną polegającą na tym, że należy badać zamiar i cel umowy, a nie opierać się na jej dosłownym brzmieniu.

${ }^{13} \mathrm{Na}$ gruncie prawa unijnego pomocne w zakresie wykładni przepisów jest to, że wiele tych regulacji wprost określa cele, dla których dany akt został przyjęty i które winny być realizowane. Jest to preambuła danego aktu prawnego, a w przypadku RODO postanowienia zawarte w preambule określane są jako motywy. 
zbiorowe” czy „porozumienia z przedstawicielami pracowników” (o czym dalej), to nie można uznać, że w prawie krajowym brak jest podstawy prawnej do zawierania takich porozumień. Uprawnienie to wynika wprost $\mathbf{z}$ prawa unijnego. Stąd zasadne jest „na wzór” sądownictwa uznanie, że skoro sądy krajowe są swoistego rodzaju oddziałami Trybunału Sprawiedliwości Unii Europejskiej, to prawo krajowe jest swoistym działem prawa unijnego, a więc w celu zachowania kompatybilności (spójności) musi być $\mathrm{z}$ nim zgodne. Jest mianowicie w przestrzeni konstrukcyjnej elementem prawa unijnego.

2. Za uznaniem, że RODO może stanowić podstawę zawierania porozumień zbiorowych, przemawia to, iż powyższy akt prawny spełnia przesłanki wynikające $\mathrm{z}$ art. 9 k.p. również $\mathrm{w}$ tym zakresie, iż:

- odwołuje się w licznych przepisach bezpośrednio do zagadnień pracowniczych,

- określa niejednokrotnie prawa i obowiązki pracowników i pracodawców, a więc stron stosunku pracy,

- jak wspomniano powyżej, wprost używa określeń „porozumienia zbiorowe” lub „porozumienia z przedstawicielami pracowników”.

$\mathrm{W}$ zakresie prawa pracy istotne $\mathrm{w}$ tym względzie są postanowienia zawarte zarówno w tak zwanych motywach, jak i w samej treści RODO. Otóż motyw 155 stanowi, że:

W prawie państwa członkowskiego lub w porozumieniach zbiorowych, w tym zakładowych porozumieniach z przedstawicielami pracowników, mogą być przewidziane przepisy szczegółowe o przetwarzaniu danych osobowych pracowników w związku z zatrudnieniem, w szczególności warunki, na których dane osobowe w związku z zatrudnieniem można przetwarzać za zgodą pracownika do celów procedury rekrutacyjnej, wykonywania umowy o pracę, w tym wykonywania obowiązków określonych w przepisach lub w porozumieniach zbiorowych, zarządzania, planowania i organizacji pracy, równości i różnorodności w miejscu pracy, bezpieczeństwa i higieny pracy oraz do celów indywidualnego lub zbiorowego wykonywania praw i korzystania ze świadczeń związanych z zatrudnieniem, a także do celów zakończenia stosunku pracy.

Z kolei według art. 88 ust. 1 i 2 RODO:

1. Państwa członkowskie mogą zawrzeć w swoich przepisach lub w porozumieniach zbiorowych bardziej szczegółowe przepisy mające zapewnić ochronę praw i wolności w przypadku przetwarzania danych osobowych pracowników w związku z zatrudnieniem, w szczególności do celów rekrutacji, wykonania umowy o pracę, w tym wykonania obowiązków określonych przepisami lub porozumieniami zbiorowymi, zarządzania, planowania i organizacji pracy, równości i różnorodności w miejscu pracy, bezpieczeństwa i higieny pracy, ochrony własności pracodawcy lub klienta oraz do celów indywidualnego lub zbiorowego wykonywania praw i korzystania ze świadczeń związanych z zatrudnieniem, a także do celów zakończenia stosunku pracy.

2. Przepisy te muszą obejmować odpowiednie i szczegółowe środki zapewniające osobie, której dane dotyczą, poszanowanie jej godności, prawnie uzasadnionych interesów i praw podstawowych, 
w szczególności pod względem przejrzystości przetwarzania, przekazywania danych osobowych w ramach grupy przedsiębiorstw lub grupy przedsiębiorców prowadzących wspólną działalność gospodarczą oraz systemów monitorujących w miejscu pracy.

Jako bezpośredni przykład rozwiązań prawnych wynikających z RODO w zakresie porozumień zbiorowych może posłużyć zawieranie porozumień w przedmiocie prowadzenia u pracodawcy polityki w zakresie ochrony danych osobowychczy tak zwanych kodeksów dobrych praktyk, które w zakładzie pracy wprowadzałyby procedury o charakterze etycznym odnośnie do ochrony danych osobowych (Żołyński 2018).

Możliwość zawierania takich porozumień wynika wprost $\mathrm{z}$ art. 40 oraz motywu 98 RODO (na przykład Kowalczuk-Pakuła, Guzewska 2017, s. 222 i n.). Mianowicie zgodnie z art. 40 RODO między innymi państwa członkowskie winny zachęcać do sporządzania kodeksów postępowania mających pomóc we właściwym stosowaniu niniejszego rozporządzenia, z uwzględnieniem specyfiki różnych sektorów dokonujących przetwarzania. Celem kodeksów jest doprecyzowanie zastosowania rozporządzenia RODO, między innymi w odniesieniu do zgodnego $\mathrm{z}$ prawem oraz rzetelnego i przejrzystego przetwarzania danych. Artykuł ten nadaje uprawnienia do tworzenia kodeksów postępowania wszystkim administratorom przetwarzającym dane osobowe. Z kolei motyw 98 RODO wprost wskazuje, że:

\footnotetext{
Należy zachęcać zrzeszenia lub inne organy reprezentujące kategorie administratorów lub podmiotów przetwarzających do sporządzania kodeksów postępowania, w granicach niniejszego rozporządzenia, by ułatwiać skuteczne stosowanie niniejszego rozporządzenia, z uwzględnieniem szczególnych cech przetwarzania prowadzonego w niektórych sektorach i szczególnych potrzeb mikroprzedsiębiorstw oraz małych i średnich przedsiębiorstw. W takich kodeksach można w szczególności dopasować obowiązki administratorów i podmiotów przetwarzających do ryzyka naruszenia praw lub wolności osób fizycznych, jakie może powodować przetwarzanie.
}

Na marginesie należy zauważyć, że możliwość przyjmowania kodeksów postępowania wprost przewiduje także motyw 77 RODO.

Przykładem zawierania porozumień zbiorowych, a więc de facto umów zwieranych między związkami zawodowymi a pracodawcą, w sferze ochrony danych osobowych mogą być przywołane już kodeksy dobrych praktyk. Niemniej odnosząc się do kodeksu dobrych praktyk, nieodzowne jest wskazanie, że strona przedmiotowa tego kodeksu ma charakter obszerny, a katalog regulacji nim objętych ma wybitnie charakter zbioru otwartego, a zatem niezamkniętego. Mimo to niewątpliwie powinny one w swojej treści zawierać postanowienia odnoszące się stricte do sfery pracowniczej, a mianowicie zawierać między innymi postanowienia „ostrzegające” - a zatem „dyscyplinujące” - pracowników, że naruszenie przyjętych w tym dokumencie reguł może stanowić:

- naruszenie porządku i dyscypliny pracy, a zatem w konsekwencji może stanowić podstawy do zastosowania kary porządkowej (nieprzestrzeganie przez pracownika ustalonej organizacji i porządku w procesie pracy), 
- podstawę do uznania utraty zaufania pracodawcy do pracownika w zakresie sumienności i rzetelności wykonywanej pracy, a tym samym do wypowiedzenia lub nawet rozwiązania w trybie natychmiastowym umowy o pracę,

- przestępstwo stypizowane w art. $267 \$ 3$ i 4 ustawy z dnia 6 czerwca 1997 roku Kodeks karny (Dz.U. 2019, poz. 1950 tekst jedn ze zm., dalej: k.k.; podsłuch lub przekazanie wiadomości osobie trzeciej). Otóż w sytuacjach, gdy pracownik będzie groził ujawnieniem treści nagrania ze szkodą dla pracodawcy, a szantaż ten wzbudzałby uzasadnioną obawę, że zostanie spełniony, zachodzić może podstawa do uznania popełnienia przestępstwa $\mathrm{z}$ art. $190 \$ 1$ i 2 k.k. ${ }^{14}$

Osobno procedury winny zawierać:

- informację, że jeżeli w wyniku takiego zachowania została wyrządzona szkoda osobie trzeciej, którą na mocy art. 120 k.p. zobowiązany byłby wyrównać pracodawca, istnieje możliwość dochodzenia roszczenia regresowego wobec sprawcy,

- informację, że pracownik może zostać pociągnięty bezpośrednio przez pokrzywdzonego do odpowiedzialności cywilnej - z reguły będzie to powództwo o ochronę dóbr osobistych w postaci żądania przeprosin i gratyfikacji finansowej, przez żądanie zasądzenia zadośćuczynienia,

- informację, że zgodnie z art. 29 RODO pracodawca może upoważnić pracownika do przetwarzania danych osobowych innych zatrudnionych. Jednakże w przypadku gdy pracownik przekroczy zakres udzielonego mu upoważnienia przez pracodawcę do przetwarzania danych osobowych, może to stanowić podstawę do rozwiązania umowy o pracę $\mathrm{w}$ trybie dyscyplinarnym (art. $52 \$ 1$ pkt 1 k.p.; wyrok Sądu Najwyższego z dnia 4 kwietnia 2017 roku, II PK 37/16, LEX nr 2306364). Mianowicie pracownik narusza swoim zachowaniem postanowienia art. 100 $\$ 1$ k.p. (zobowiązany jest wykonywać pracę sumiennie i starannie) oraz art. $100 \$ 2$ pkt 2 k.p. (winien przestrzegać ustalonego w zakładzie pracy porządku).

Biorąc powyższe pod uwagę, polityka ta winna zawierać elementy, które będą niewątpliwie pogłębiały i zwiększały:

1) wiarygodność pracodawcy w zakresie przetwarzania danych osobowych,

2) świadomość konieczności ochrony danych osobowych,

3) zaufanie do przestrzegania prawa,

4) zdolność do ciągłego pogłębiania poufności,

5) zdolność do szybkiego usuwania danych nieaktualnych lub których usunięcia w zakresie określonym prawem zażądał podmiot objęty ochroną,

6) testowanie, mierzenie i ocenianie skuteczności przyjętych rozwiązań i zabezpieczeń technicznych mających wpływ na bezpieczeństwo przetwarzanych danych, a zatem adekwatność przyjętych zabezpieczeń,

${ }^{14}$ Na marginesie - pracodawca może złożyć wniosek do sądu o nałożenie na pracownika obowiązku naprawienia szkody wyrządzonej pracodawcy (art. $46 \$ 1$ k.k.). Pracodawca może to uczynić w procesie karnym do zamknięcia przewodu sądowego na rozprawie głównej (art. 49a ustawy z dnia 6 czerwca 1997 roku - Kodeks postępowania karnego, Dz.U. 2020, poz. 30 tekst jedn. ze zm.). 
7) przestrzeganie szeroko rozumianych zasad współżycia społecznego (norm moralnych, etycznych czy kulturowych) i społeczno-gospodarczego przeznaczenia prawa (co oznacza, że z ochrony nie będzie korzystał podmiot ujawniający na przykład wrażliwe informacje).

$\mathrm{Z}$ tego też względu przyjęte rozwiązania, ujęte przez pracodawcę we właściwe i stosowne obwarowania, mogą spowodować, że kodeks dobrych praktyk, $\mathrm{z}$ dotychczasowego instrumentu często o charakterze wybitnie wizerunkowo-promocyjnym (pijarowym), może się stać istotnym narzędziem o charakterze prawnym.

Na marginesie - nie można także zapominać, że zawieranie porozumień zbiorowych nakierowanych między innymi na ochronę danych osobowych prowadzi pośrednio do ochrony zdrowia (w szczególności psychicznego) pracowników. W wymiarze aksjologicznym służy zatem także pośrednio ochronie dobra w postaci bezpieczeństwa i interesu państwa jako wspólnoty ludzkiej. Ochrona zdrowia pracowników realizowana jest mianowicie ze środków publicznych, gdyż środki finansowe gromadzone z obowiązkowych danin nałożonych na pracowników nie służą tworzeniu prywatnego kapitału zdrowotnego danej osoby (w przeciwieństwie do środków gromadzonych na funduszach emerytalnych). Stąd wszelkie działania zmierzające do ograniczenia wypłaty świadczeń zdrowotnych służą dobru wspólnemu, jakim jest dobro państwa (dobro społeczeństwa).

Na koniec wyraźnie pragnę zaznaczyć, że podstaw do zastosowania RODO jako źródła prawa pracy można, a wręcz należy poszukiwać także w aksjologii i filozofii prawa.

Po pierwsze - Polska cywilizacyjnie i prawnie należy do jednolitej wspólnoty zachodniej, jaką jest Unia Europejska. Przynależymy zatem cywilizacyjnie do grupy społeczno-kulturowej o najszerszym z możliwych stopniu samoidentyfikacji tożsamościowej także w zakresie prawa. Mianowicie wspólne składowe prawa państw unijnych, wywodzące się genetycznie z prawa rzymskiego, tworzą między sobą specyficzną sieć wzajemnych relacji, powiązań, co prowadzi do preferowania rozwiązań wspólnotowych o małej dyferencjacji prawnej, niemniej uwzględniających specyfikę członków wspólnoty. Wyznajemy zatem w prawie te same wartości wywodzące się z etyki i moralności ludzkiej (w szczególności chrześcijańskiej), stojące ponad podziałami etnicznymi, społecznościowymi, kulturowymi czy politycznymi. W warstwie aksjologiczno-filozoficznej w danym momencie dziejowym preferujemy ten sam typ wartości funkcjonującego systemu społeczno-polityczno-prawnego, opartego na szeroko rozumianych prawach człowieka.

Po drugie - wartością chronioną jest dobro człowieka (pracownika) w postaci eliminowania stanu zagrożenia jego prywatności. Według motywu 1 RODO ochrona osób fizycznych w związku z przetwarzaniem danych osobowych jest jednym z podstawowych praw. (Odwołuje się w tym zakresie do art. 8 ust. 1 Karty praw podstawowych $\mathrm{UE}^{15}$ oraz art. 16 TFUE). Jak wspomniano wcześniej, dane osobowe pracownika są

${ }^{15}$ Karta praw podstawowych Unii Europejskiej (ang. Charter of Fundamental Rights of the European Union, fr. Charte des droits fondamentaux de l'Union Européenne; Dz.Urz. UE C 2010, nr 83) stanowi zbiór fundamentalnych praw człowieka i obowiązków obywatelskich uchwalony i podpisany 7 grudnia 
pochodną prywatności, podzbiorem pojęcia prywatność, a więc zachodzi funkcja zawierania. Chroniąc prywatność, pośrednio chronimy zdrowie, a nawet życie pracownika, które mogą być zagrożone przez bezprawne naruszanie sfery prywatności (wywołany tym stanem stres, zaburzenia psychiczne, ogólny rozstrój organizmu itp.). Szerzej: podstawą do postawienia takiej tezy jest także to, że w znaczeniu largo rozumienia polityka bezpieczeństwa w zakresie ochrony danych osobowych może być ono przedmiotem porozumień zbiorowych, gdyż zbiorowe prawo pracy w swojej istocie jest najbardziej indywidualną częścią prawa pracy ${ }^{16}$. Ostatecznie bowiem w wyniku tych regulacji beneficjentami tych praw stają się pracownicy (Sobczyk 2014). Akty wewnątrzzakładowe o charakterze umów zbiorowych niewątpliwie podwyższają poziom ochrony pracowników względem regulacji publicznoprawnych.

\section{Podsumowanie}

Analiza przedmiotowego zagadnienia zmusza do uznania, że pewne regulacje unijne, jak rozporządzenie RODO, które po przyjęciu (z upływem określonego vacatio legis) weszło bezpośrednio do polskiego systemu prawnego, należy uznać za źródło prawa pracy. Wobec powyższego zawieranie na podstawie takiej regulacji porozumienia zbiorowe należy uznać za „swoiste” źródła prawa pracy ${ }^{17}$. W konsekwencji porozumienia zbiorowe zawierane na podstawie tego aktu stają się obowiązującym źródłem prawa pracy w Polsce, a zatem mają charakter normatywny. Powoduje to, że porozumienia zbiorowe opierające się na rozwiązaniach przyjętych w RODO wymuszają na pracodawcy i innych uczestnikach zbiorowych stosunków pracy lepsze i bezpieczniejsze zarządzanie danymi osobowymi, a w ten sposób zwiększają ochronę prywatności pracownika, wymuszają większą kontrolę i bezpieczeństwo własnych sieci internetowych pracodawcy (intranetu i extranetu), co w konsekwencji przekładać się winno na znaczne zmniejszenie podatności na potencjalne zagrożenia. Takie porozumienia wymuszają taką samą kontrolę przez czynnik społeczny, jakim są w szczególności zakładowe organizacje związkowe czy rady pracowników.

2000 roku podczas szczytu Rady Europejskiej w Nicei w imieniu trzech organów Unii Europejskiej: Parlamentu, Rady oraz Komisji; powtórnie, z pewnymi poprawkami, podpisany przez przewodniczących tych organów podczas szczytu w Lizbonie 12 grudnia 2007 roku. Moc wiążąca dokumentu została mu nadana przez traktat lizboński podpisany 13 grudnia 2007 roku, który wszedł w życie 1 grudnia 2000, Dz.Urz. UE C 2010, nr 83/02.

${ }^{16}$ Przykładowo Trybunał Konstytucyjny 6 czerwca 2018 roku uznał, że niektóre regulacje prawne zawierają luki prawne i wymagają wręcz pilnej zmiany przepisów (K 53/16, OTK-A 2018, poz. 38). Z tego też względu, z uwagi na to, że proces legislacyjny generalnie jest długotrwały, „poprawienie” regulacji ustawowej na korzyść pracowników może być dokonane w formie porozumienia zbiorowego.

${ }^{17} \mathrm{~W}$ doktrynie prawa pracy kategoria „swoistych źródeł prawa pracy” wyróżniana jest przede wszystkim w opozycji do wskazanych w art. 87 Konstytucji źródeł prawa powszechnie obowiązującego. "Swoistość" tych źródeł prawa wynika między innymi z tego, że są tworzone przez specjalnie upoważnione do tego podmioty w określonym ustawowo szczególnym trybie (Włodarczyk 2010, s. 398 i n.). 
Wprowadzenie $\mathrm{w}$ wyniku porozumień zbiorowych dodatkowych przesłanek ochrony danych osobowych osób zatrudnionych (a więc nie tylko pracowników sensu stricto) jest dodatkową gwarancją ochrony prywatności. Należy mianowicie mieć na uwadze, że regulacje RODO, oprócz sankcji o charakterze typowo administracyjnym, nie przekreślają możliwości stosowania sankcji karnych wobec sprawców naruszenia ani ich ewentualnej odpowiedzialności cywilnej za szkody wywołane w wyniku sprzecznego z prawem przetwarzania danych, a w konsekwencji naruszenia prywatności pracownika. Niemniej - co wymaga wyraźnego podkreślenia - RODO stawia na człowieka, a zatem chroniony jest czlowiek z samej swej istoty, dlatego że jest człowiekiem (szczególnym podmiotem w świecie). Ta regulacja stawia zatem w pierwszej kolejności na ochronę godności w znaczeniu osobowym, a następnie - już na żądanie zainteresowanego - na ochronę osobistą. Jednocześnie należy zwrócić uwagę, że ochrona danych osobowych ma charakter następczy. Chroniony jest człowiek przez ochronę jednej ze sfer, która wymaga jego ochrony, a mianowicie wielokrotnie przywoływanej już sfery prywatności. Ma to istotne znaczenie na przykład w dochodzeniu roszczeń z tytułu zadośćuczynienia, gdyż w dochodzeniu tych roszczeń nie jest wymagane wykazanie poniesionej szkody, a więc poszkodowany nie musi dochodzić swoiście rozumianego odszkodowania. Wystarczy sam fakt, że doszło do naruszenia zasad ochrony danych osobowych (Żołyński 2018).

Kończąc, należy także zwrócić uwagę, że:

1. Szeroko rozumiane regulacje dotyczące ochrony danych osobowych nie dają się zakwalifikować tylko i wyłącznie do jednej dziedziny prawa. $Z$ materii tej regulacji wynika, że stanowią swoistą kompilację prawa konstytucyjnego, praw człowieka, prawa cywilnego, administracyjnego, karnego, a także prawa pracy.

2. Podstaw przyjęcia tych regulacji należy poszukiwać w prawach człowieka (w I kategorii praw człowieka), w ich podstawowych założeniach aksjologiczno-filozoficznych. Mają one zatem charakter interdyscyplinarny.

\section{Bibliografia}

Banaszak B. (2012) Konstytucja Rzeczypospolitej Polskiej. Komentarz, Warszawa.

Cieśliński A. (2003) Wspólnotowe prawo gospodarcze, Warszawa.

Emmert E., Morawiecki M. (2002) Prawo europejskie, Warszawa-Wrocław.

Florczak I, Muszyńska B. (2014) „Metoda matematyczna” badań Kodeksu pracy - kodeks pracy w statystyce (materiały do Drugich Wrześniowych Spotkań z Prawem Pracy. 40-lecie Kodeksu pracy, 12-14 września 2014 roku).

Florek L. (1997) Konstytucyjne gwarancje uprawnień pracowniczych, „Państwo i Prawo”, z. 11-12. Florek L. (1998) Pojęcie, źródła i charakter europejskiego prawa pracy, „Praca i Zabezpieczenie Społeczne", nr 7-8.

Florek L. (2000) Rola umów międzynarodowych w zbiorowym prawie pracy [w:] G. Goździewicz (red.), Zbiorowe prawo pracy w społecznej gospodarce rynkowej, Torun. 
Florek L. (2004) Znaczenie wspólnotowego prawa pracy, „Praca i Zabezpieczenie Społeczne”, nr 5. Haczkowska M. (2014) [w:] M. Haczkowska (red.), Konstytucja Rzeczypospolitej Polskiej. Komentarz, Warszawa.

Jaśkowski K. (2007) Porozumienia zbiorowe w prawie pracy [w:] L. Florek (red.), Indywidualne a zbiorowe prawo pracy, Warszawa.

Kowalczuk-Pakuła I., Guzowska M. (2017) Kodeksy postępowania w rozporządzeniu ogólnym o ochronie danych osobowych - szansa dla administratorów $w$ zakresie wypetniania nowych obowiązków, transferów danych i przetwarzania danych pracowniczych [w:] D. Dörre-Kolasa (red.), Ochrona danych osobowych pracowników w świetle rozporządzenia Parlamentu Europejskiego i Rady (UE) 2016/679, Warszawa.

Lityński P. (2017) Publicznoprawna ochrona danych osobowych [w:] D. Dörre-Kolasa (red.), Ochrona danych osobowych pracowników w świetle rozporządzenia Parlamentu Europejskiego $i$ Rady (UE) 2016/679, Warszawa.

Longchamps F. (1964) O pojęciu stosunku prawnego w prawie administracyjnym, „Acta Universitatis Wratislaviensis", nr 19.

Nowak P. (2018) Sprawdzanie kandydatów do pracy pod kątem zawartości ich profili na portalach społecznościowych - analiza w świetle RODO i Kodeksu pracy, „Monitor Prawa Pracy”, nr 8.

Rot H. (1992) Wstęp do nauk prawnych, Wrocław.

Sanetra W. (2006) O roli Sądu Najwyższego w zapewnianiu zgodności z prawem oraz jednolitości orzecznictwa sądowego, „Przegląd Sądowy”, nr 9.

Sanetra W., Szurgacz H. (1975) Problemy metodologiczne badań empirycznych w prawie pracy [w:] W. Sanetra (red.), Zagadnienia metod prawoznawstwa, Wrocław.

Sobczyk A. (2014) Prawo i człowiek pracujący: między ochroną godności a równości [w:] M. Skąpski, K. Ślebzak (red.), Aksjologiczne podstawy prawa pracy i ubezpieczeń społecznych, Poznań.

Świątkowski A.M. (2008) Stosowanie konwencji MOP i traktatów Rady Europy przez krajowe sądy pracy, „Monitor Prawa Pracy”, nr 6.

Walczak K. (2017) [w:] K.W. Baran (red.), Prawo pracy i ubezpieczeń społecznych, Warszawa.

Włodarczyk M. (2010) Swoiste źródła prawa pracy [w:] K.W. Baran (red.), Zarys systemu prawa pracy, t. 1, Warszawa.

Wronkowska S. (2005) Podstawowe pojęcia prawa i prawoznawstwa, Poznań.

Wróbel D. (2012) [w:] D. Kornobis-Romanowska, J. Łacny, A. Wróbel (red.), Traktat o funkcjonowaniu Unii Europejskiej. Komentarz, t. 3, Warszawa.

Żołyński J. (2014) Glosa do wyroku SN z dnia 4 września 2013r., II PK 358/12, „Praca i Zabezpieczenie Społeczne", nr 3.

Żołyński J. (2016a) Aksjologiczne, normatywne i społeczne podstawy prawa rozwiązywania sporów zbiorowych pracy, Gdańsk.

Żołyński J. (2016b) Prawo pracy - prawo prywatne czy prawo publiczne. Rozważania na tle charakteru umowy o prace, „Studia z Zakresu Prawa Pracy i Polityki Społecznej”.

Żołyński J. (2018) RODO - prawo do zapomnienia w sferze zatrudnienia, Warszawa. 


\section{Orzecznictwo}

Wyrok Trybunału Konstytucyjnego z dnia 18 października 2005 roku, SK 48/03, OTK-A 2005, nr 9, poz. 101.

Wyrok Trybunału Konstytucyjnego z dnia 24 października 2006 roku, SK 41/05, Dz.U. 2006, nr 198, poz. 1464.

Wyrok Trybunału Konstytucyjnego z dnia 12 lipca 2010 roku, P 4/10, Dz.U. 2010, nr 135, poz. 912. Wyrok Trybunału Konstytucyjnego z dnia 22 maja 2013 roku, P 46/11, Dz.U. 2013, poz. 653. Wyrok Sądu Najwyższego z dnia 4 września 2013 roku, II PK 358/12, LEX nr 1460947. Wyrok Sądu Najwyższego z dnia 19 lutego 2014 roku, II PK 131/13, MPP 2014, nr 7. Wyrok Sądu Najwyższego z dnia 4 kwietnia 2017 roku, II PK 37/16, LEX nr 2306364.

Wyrok Trybunału Konstytucyjnego z dnia 6 czerwca 2018 roku, K 53/16, OTK-A 2018, poz. 38.

\section{Akty prawa międzynarodowego}

Traktat o utworzeniu Europejskiej Wspólnoty Gospodarczej (tzw. traktat rzymski), podpisany 25 marca 1957 roku (wszedł w życie 1 stycznia 1958 roku), Dz.U. 2004, nr 90, poz. 864/2.

Traktat o utworzeniu Europejskiej Wspólnoty Energii Atomowej (tzw. traktat rzymski), podpisany 25 marca 1957 roku (wszedł w życie 1 stycznia 1958 roku), Dz.U. 2004, nr 90, poz. 864/3.

Jednolity Akt Europejski podpisany 17 lutego 1986 roku (Luksemburg) oraz 28 lutego 1986 roku (Haga) (wszedł w życie 1 lipca 1987 roku), Dz. Urz. WE 1987 L 169, s. 1.

Traktat o Unii Europejskiej (tzw. traktat z Maastricht), podpisany 7 lutego 1992 roku (wszedł w życie 1 listopada 1993 roku), Dz.U. 2004, nr 90, poz. 864/30.

Traktat z Amsterdamu zmieniający Traktat o Unii Europejskiej, traktaty ustanawiające Wspólnoty Europejskie i niektóre związane z nimi akty (tzw. traktat amsterdamski), podpisany 2 października 1997 roku (wszedł w życie 1 maja 1999 roku), Dz.U. 2004, nr 90, poz. 864/31.

Karta praw podstawowych Unii Europejskiej z dnia 7 grudnia 2000 roku, Dz.Urz. UE C 2010, nr 83.

Traktat z Nicei zmieniający Traktat o Unii Europejskiej, traktaty ustanawiające Wspólnoty Europejskie i niektóre związane z nimi akty (tzw. traktat nicejski), przyjęty 11 grudnia 2000 roku i podpisany 26 lutego 2001 roku (wszedł w życie 1 lutego 2003 roku), Dz.U. 2004, nr 90, poz. 864/32.

Traktat z Lizbony zmieniający Traktat o Unii Europejskiej i Traktat ustanawiający Wspólnotę Europejską, sporządzony w Lizbonie dnia 13 grudnia 2007 roku, Dz.U. 2009, nr 203, poz. 1569.

Traktat ustanawiający Wspólnotę Europejską, Dz.Urz. UE C 2012, nr 326/47

Traktat o funkcjonowaniu Unii Europejskiej - wersja skonsolidowana Traktatu o Unii Europejskiej i Traktatu o funkcjonowaniu Unii Europejskiej, Dz.Urz. UE C 2016, nr 202, s. 1.

Rozporządzenie Parlamentu Europejskiego i Rady (UE) nr 2016/679 z dnia 27 kwietnia 2016 roku w sprawie ochrony osób fizycznych w związku z przetwarzaniem danych osobowych i w sprawie swobodnego przepływu takich danych oraz uchylenia dyrektywy 95/46/WE (ogólne rozporządzenie o ochronie danych), Dz.Urz. UE L 2016, nr 119/1. 


\section{Akty prawa krajowego}

Konstytucja Rzeczypospolitej Polskiej z dnia 2 kwietnia 1997 roku, Dz.U. 1997, nr 78, poz. 483 ze zm.

Ustawa z dnia 23 kwietnia 1964 roku - Kodeks cywilny, Dz.U. 2019, poz. 1145 tekst jedn. ze zm. Ustawa z dnia 26 czerwca 1974 roku - Kodeks pracy, Dz.U. 2019, poz. 1040 tekst jedn. ze zm. Ustawa z dnia 6 czerwca 1997 roku - Kodeks karny, Dz.U. 2019, poz. 1950 tekst jedn. ze zm. Ustawa z dnia 6 czerwca 1997 roku - Kodeks postępowania karnego, Dz.U. 2020, poz. 30 tekst jedn. ze zm.

Ustawa z dnia 10 maja 2018 roku o ochronie danych osobowych, Dz.U. 2019, poz. 1781 tekst jedn. 